\title{
The Concept of Power in Suzzane Collins' The Hunger Games
}

\author{
Ismail Tahir
}

\author{
Graduate Program in English Language Teaching, Universitas Negeri Malang, Indonesia \\ Bachelor Degree in Letters and Culture Faculty, Universitas Negeri Gorontalo, Indonesia
}

\begin{abstract}
This research explores the concept of power in Suzzane Colllins' work The Hunger Games novel which focuses on the characteristic of power. It is conducted by using a qualitative method. The data were taken from this novel as the source data. The research question "How is the power in Suzzane Collins' The Hunger Games" is aimed to identify the kinds of characteristics of power and to analyze the meaning of each power characteristic found in Suzzane Collins' novel. There were four steps of collecting data namely; identification, exploration, description, and explanation. The analyzing data was as follow; organize-elaborate-synthesize-analysis. Furthermore, this research is analyzed by using Marxist criticism as an approach to seek how is the concept of power categorized based on Karlberg' theory of the characteristic of power namely; the power as domination and power as capacity. As the result, this research found out that Marx's perspective through the concept of power is power capacity is caused by power domination. Additionally, Marx's views about power domination, it does not only occur between upper and lower class but it also occurs among the lower class.
\end{abstract}

Keywords-Concept of power, Characteristic of power, Marxist approach

\section{INTRODUCTION}

Conceptualizing power means the foundation of the society which people can have the relationship one another (Castells, 2011). This argument brings our mind to know more about the concept of power that is used for our social life. The concept of power takes a place for human's position to have any relationship whether in the environment, international relations, political science, economics, or in sociology (Cerbaro, 2011). Basically, every human has a power which they can use for taking that relation with another. They can also use their power in their own way. Similarly, they can control the use of their power by themselves (Naik, 2011).

This study presents the concept of power in Suzzane Collins' "The Hunger Games" which is used the Marxist as the approach to analyze the concept of power in this novel. The Hunger Games novel is a gripping novel, especially for a young adult. It provides the understanding many essential questions and big ideas behind of the story. To illustrate, there are some people who participate in an extreme event every year but they actually really do not want to follow it. It is because they have to fight each other to be one as a winner of this event.

Additionally, the thing that is interested to analyze from this story is when all the selected participants will stay in the arena and they will fight each other to the death. Therefore, every participant should have a strong power to survive when they are in Dystopia. In other words, few people actually have any power in The Hunger Games, other than their personal skill to survive. In the same way, as the main character in this novel who was a volunteer to change her sister place, Katniss more qualities to fight in the games than her sister. It is because she is a stronger and a trained girl in her family. That is why Katniss does not originally get chosen for the Hunger Games.

This study applies Marxist in analyzing the concept of power by having more sentences that related to the concept of power. The Marxist approach is an appropriate approach to analyze the concept of power which is told in this story. It is because the Marxist investigates all the social phenomena and it is as the knowledge of humanism which considers the freedom and human right as the most important thing in society. This phenomenon is told in The Hunger Games which is the history of class struggles. It happens between the society or all twelve districts and the government of Panem. This story presents the differentiation two types of social class which is the high and the low class or bourgeoisie and proletariat. The bourgeoisie has reflected the governments and the proletariat are reflected all society of twelve districts.

Besides, this study only presents the characteristic of power which shows the concept of power. The characteristics of power here are the power as domination and the power as the capacity (Karlberg, 2005). The domination power will present anything happens in social phenomenon while the capacity will investigate all the result of what happened in social phenomenon of the story in The Hunger Games novel. Thus, the title of this research is "The Power in Suzzane Collins' "The Hunger Games". 


\section{THEORETICAL BASIS}

\subsection{The Meaning of Power}

There are some previous studies that have analyzed the concept of power. The concept of power showed the human's intuitive notion to get the relationship among people of social phenomenon. Every person had a power inside of his/her body. Power could be passive and active. The passive power could be from the body heat, breathing, blood pressure, emotion, typing, and walking while the active power through the action (The Energy Harvesting Network, 2011). This theory supports the topic that is going to discuss on this topic. It will seek the human's power either in passive or in active power. This study analyzes some sentences inside of the novel and it can show the characters' passive and active power. It can be seen from a sentence or some sentences. To be specific, when Katniss' sister was chosen as the tribute of the games, Katniss was a volunteer to change her sister to be a tribute to the games.

However, The Hunger Games novel tells about the social networks and its environment. Castells (2011) argued that power exercised the human's social networks. The power process had to pay attention by two perspectives. The power process had the existing of domination. The human had the right to get domination because of the power. On the other hand, the power process did not need to establish of domination especially on behalf of the interest, values, and projects that were excluded in social networks. He argued that the social power was the history. The power had a relationship between the social networks and the communication. People would think how they lived in their life and how they related to the culture of the economy and society. Therefore, these statements can be a ground theory of analyzing the government's and individual's power, and its relation to the social class.

To sum up, based on some concepts of power above, it could be explained that power is shown a person or some of which are more powerful than others who compete each other in a variety of groups in a society. On the other hand, power could also define as the integral dynamic of the politics. It showed a degree of some aspects control in a society like the material, human, intellectual, and the financial resources. Those are aspects to see the individual source and social power. Similarly, the power is dynamic and relational. It could be moved to another side and it had the connection each other among individual, individuals, and groups which are consist of in the social, economic, and political. In addition, Afolayan (2011) concerned the important contribution of the socio-economic and the political aspect in a social phenomenon.

\subsection{The Characteristic of Power}

Michael Karlberg (2005) analyzed the characteristic of power which consists of power as domination and power as capacity.

\section{The Power as Domination}

The power as domination focused on the social and political theory. Power is viewed the social resource. It could be the reality of what happened in the people environment such as the number of people to get the work, the materials in economic production, the number of people who have been born and died, and the available social resource in a society. The Hunger Games novel concerns all the phenomenon above such people to get something for their life, all the material productions, the number of people who have been born and died, and the social resource in the whole of that story.

Additionally, Cerbaro (2011) argued about the power in political science. As the politicians who could influence people by seeing the rank of each politician. It means that by having the rank, it could be seen the politicians as being more or less powerful based on the total of people that they influenced.

\section{The Power as Capacity}

The whole of the Hunger Games provides the human's ability to fight to the death. Additionally, this is also showed how every person in this story uses their skill to survive. As the power of domination that has the relation with social and political theory. The power of capacity has the function to get the results or the outcomes of what in social and political. Additionally, the power of capacity also has associated with the ability, capacity, and competence.

\subsection{The Types of Power}

The Hunger Games novel emphasizes the government's and individual's power and its relation to the social class. It shows how the government can lead their people to their domination. Lakey (2009) emphasized in Sharing Leadership in Our Organizations article that there were three types of power. They could be the power-over, power-with-others, and power-from-within.

\section{Power-Over}

This is the type of showing an ability to against people's will to make them doing something. People who have more power than another, they will use it for leading the other people who are in their lower position but the other people actually do not want to do it. To be specific, to force someone or people do something about what they do not like to do.

\section{Power-With-Others}

Power-With-Others has a meaning to influence and to make someone or people take actions in order to make them as a unit each other. Actually, people who have the 
higher power in a social life, they can lead the lower power by influencing them to do something but it is proposed to make them in a unit or they will collaborate one another. In this case, there will be no any differentiation among people in the social life.

\section{Power-From-Within}

This is one of those types that has a meaning as the capability to give some influences and make someone or people take actions based on intention, the clear vision, and someone's interest (charisma). This statement means that someone has confidence in what he/she does and he/she believes that he/she is right. Moreover, this means also if someone believes about his/her ability, he/she believes that he/she can achieve something.

\subsection{Marxist Literary Criticism}

Marxist Criticism is usually based on the doctrine of The Communist Manifesto (1848) which is argued by Karl Marx and Friedrich Engels. Marx argued that literature and all of other cultures showed the relationship in the economic life. It was because the literature was bunched by some classes in a social environment. Therefore, the literary work can be understood by connecting those relations (Eaglaton, 1976). By having this argument, the Marxist Criticism is oriented on the political issues. It investigates the world's views which declared briefly. On the political issue, it shows the class struggle, free for a political system, democracy, and the election. There were no different classes in a country. Everyone has the same right to participate in the political system. Further, the basic idea of this criticism is Karl Marx's social theory. It emphasizes the social networks among the society. On the other hand, the use of the language of this criticism is influenced by social class and economy. Therefore, every text on literary work can be shown those aspects. To be specific, the text in the Hunger Games can be found some statements of ideologies such as the class, economy, and domination. It reflects the importance of those ideologies in competing for each other.

Importantly, this type of criticism can be used to analyze the topic in this study. The topic seeks how the relationship between the government's and individual's power, and its relation to the social class. To analyze to topic by applying this approach is helping this study to be easier in finding some examples of the topic. Besides, it can also answer all the questions that have arisen. Therefore, it is the best tool for analyzing the topic. Marxist Criticism is convinced to criticize the literature works especially the use of language in reflecting the differentiation among the politic, the social class, and economy. To be specific, it can be some ideologies like class, economy, race, and domination. To sum up, the
Marxist Criticism uses for criticizing the political structures and economy who have dominated.

\section{METHODOLOGY OF RESEARCH}

\subsection{Method of Research}

This research uses the qualitative method. Sugiyono (2009) explained that the qualitative method has four meanings. They are as the new method, a positive philosophy, an art, and interpretive method. It is because the qualitative method is to understand the social reality which is in the conditional nature. Therefore, someone who wants to conduct a research should have known about the theory and what the researcher is going to conduct research in order to make the researcher can ask, analyze, and construct the research objects. Besides, the qualitative method is used if the problem is still unclear, to know the hidden meaning, to develop the theory, to make sure the truth of the data, and to know the development of the history. Moreover, someone who wants to use the qualitative method should have the skill or ability, bravery, keep the social networking, and open-minded.

This research is conducting to figure out the concept of power in Suzzane Collins's first section of the novel in the hunger games. The qualitative method will be used in this research because by having the data inside the novel which are showing the power, it can analyze without having the statistics analyze. To illustrate, the data in a sentence does not count the each letter, word, phrase, or the sentence itself but it analyzes with figuring out the meaning of the sentence.

\subsection{Approach}

The method that used in this research is a qualitative method and it describes the concept of power in Suzzane Collin's novel “The Hunger Games". This research is also used Marxist approach, which is a research toward the domination and capacity power as the characteristics in the concept of power.

\subsection{Data and Source of the data}

In this research, the source data is the novel itself "The Hunger Games" and the data can be collected by having a sentence or some sentences inside of the novel.

\subsection{Technique of Collecting Data}

This research emphasizes to use the source of collecting data. To find out the meaning of the data just is suitable examined by the qualitative method. The steps of collecting the data in this research, as follow: identify explore - describe - explain.

In the "identify" step, the data can be recognized of showing that it exists on the topic. Next, in the "explore" step, the data will be thought or talked it in order to find 
out more about it or to make it sure that it relates to the topic. Then, in "describe" step, the data will be said or written that it is like of the topic. After that, the "explain" step, the data will be discussed more to make it clear or easy to understand by describing or giving information about the topic. Additionally, on this step, the data will be judged or decided the value, the quality, and the representative of the meaning of the concept of power.

\subsection{Technique of Analyzing Data}

The analyzing data is the last step in the qualitative method. In this step, it will have a free explanation or there is a free chance to write an analysis in a research by answering the questions. Therefore, it can be interesting to read.

Here are some steps of how to analyze the data in this research. (1) to organize the data, (2) to elaborate the data in a unit, (3) to synthesize the data, (4to decide the data for the writing of analysis.

\subsection{Writing a Marxist Analysis Interpretation}

Before having any data that is to analyze in the discussion, rise some opinions about the topic. It will help to explain some reasons that are related to the topic. It can be a particular way and part of showing a piece of each example of this topic. Besides, it expresses the ideas about the intended meaning of what is going to discuss on this topic.

\section{Prewriting}

Before writing a Marxist analysis, make a list of some questions that can guide to analyze a literary work. It can help to have more materials of what to begin with prewriting. In prewriting, have the stronger statements or opinions and use them as the basis of a free-writing.

\section{Drafting and Revising}

\section{The Introduction}

The effectiveness of the Marxist analysis is to announce the ideology of the text that is going to analyze with its relationship to Marxist views. It is because in the writer's essay concerns of where and how the ideology is about. The writer also can share about what the writer can understand the literary works.

\section{FINDINGS AND DISCUSSIONS}

\subsection{Research Finding and Discussion}

\section{The concept of power in the Hunger Games}

Power as Domination

Power domination in Position

The position is the essential thing to see how someone's role in a society is. Additionally, this means also where is someone to place in a right place which has a relationship with others, also where is someone able to do something because of an experience that his//her has, authority or money. Based on this idea, when someone has different or many experiences, authority, or money in a society, means that someone will have different position also in an environment. For example, a person who has much money and sources in society, that someone can do many things and can dominate the others by ordering the lower people than him/her. For example, they can buy many things, they can go anywhere, and even they can make the people do what they want. In this case, people who have much money, they will dominate people who do not have much money. This idea can be proved in Hunger Games story. That is in data 1, "Look how we take your children and sacrifice them and there's nothing you can do. If you lift a finger, we will destroy every last one of you. Just as we did in District. These words present the rules of the Hunger Games which are announced by Mayor Undersee. He uses the words "look, sacrifice, lift, destroy" on his announcement. Those mean the command from the government to all people in this District, and they must do it. By saying "look", means the government wants all the people to face to their rule, no one can against. "sacrifice" means people have to present the things that the government wants. "lift" means people have to agree with them, whatever the government does, they have to deal with it. "Destroy" means the government will damage them so badly if they will not exist and do for them. At the same time, Major Undersee announces the thing that everyone has to know about the hunger games especially for each person who is chosen for following the hunger games. People have to know why they have to follow to be the tribute for this event. The tribute who can be winning for this event, the Capitol will give more food for the District the tribute belongs. Moreover, taking the young man and woman from each District while people watch that, this is the Capitol's way to remind their people of how totally they are in the Capitol's mercy. The Capitol requires them to treat the Hunger Games as a festivity. Conceptualizing, this data is contained on the characteristic of power as domination. It is because the governments dominate people in doing the Hunger Games. Karlberg (2005) emphasizes that all the things that happen in a society like the number of people who born and death, the sources, etc., especially the number of people who are lead by the Governments of the Capitol.

Further in data 2 "Feed it to the pig, you stupid creature" and data 3 "well, try and pretend! Snaps Effie". In data 2, it indicates the situation happening between Peeta and his mother. It is when his mother orders him to do something, and this is a must. His mom does this because she knows she is his mom. In a family, mom is a higher position than 
a son or a daughter. Every son or daughter has to obey their parents, mom, and dad. His mom uses the word "pig" to command his son means she is really angry and she wants him to it quickly. Based on Cambridge dictionary, pig means to be very difficult or unpleasant to do something, and also means a person who eats too much. By knowing this definition, the "pig" here is referring to Katniss who is in front of their bakery. Katniss refers to a "pig". It is because she is an unpleasant person and she needs food to eat.

Based on Marxist, people who have more sources than the others, they will dominate them. This happens when Katniss is a lower than Peeta's family. Peeta's family has a bakery for taking the money while Katniss and her family does not have anything unless her skill in hunting some animals in the forest for their meals every day. This does not only happen between people and people in District twelve but it also happens to the government and those people like in data 3 "well, try and pretend! Snaps Effie". This shows how the government who has a higher position than Katniss, they dominate people who are from District. it is when Effie as the government representative orders and forces Katniss to do something. Here, Effie snaps at her. Literary, snap means voice out the sound loudly and angrily. She does this because she knows she has a higher position than Katniss. It can be said that the higher position someone gets, the more dominant he/she is.

Based on Marxist, the proletariat as the lower class always presents the things only for the upper class. In this case, Katniss is the lower class who does not have enough sources while the government of the Capitol has many things. This is the way that Effie stands up about.

\section{Power domination in Knowledge}

Gabrenya (2008) emphasized that the social class will be influenced by the cognitive environment whereas the cognitive environment will provide someone's behavior, tutoring, and environment. Then, that would be provided as the outcome of their IQ and the achievement. The willingness of having a power has been inside of someone's self. It has happened when someone born until the day of the death. During someone's life, there will be power in physic and mental. The physic power can be indicated someone's action. It will show how someone does and acts something.

Based on Marx in Swardhani (2012), it is a mode of the production of material life condition, especially in intellectual life. This brings our idea about the driver and the transportation. When a rider can ride well the motorbike, so the rider can control well that transportation. By seeing this illustration, it can be explained that knowledge holds a big role in ordering something. If someone has a better position in education or knowledge, it can give him/her a chance to order.

Power domination in Experience

Experience is the thing that happened in someone's life. This is all the things that someone feels. It can be various event like funny, sadness, and/or happiness. Basically, all people have different experiences even they live in the same place, they have the same age and activities. To illustrate, in a family which consists of two sons with the same age and similar face. Their family always offers them the same clothes and food. Also, they are provided the same activity like going to school together. As the fact, they got a different experience such as the son A can understand well a math subject while the son B cannot. In a similar way, the Hunger Games provides the challenge to all selected tributes to fight each other. They will stay in one place but they have a different experience of course. Sometimes, people who have more experiences than the others, they will dominate people who are lower than them because they do not know many things. It can be proved in data 5 "so, you're supposed to give us advice". This situation shows the conversation between Haymitch, Peeta, and Katniss. In this case, Peeta and Katniss do not have experiences as many as Haymitch. And they realized it. That is why they beg Haymitch to guide them. In other words, they have to do what Haymitch says. Whatever it is, it will be an obligation to them. Even they do not want to do it, they have to do it.

Marx argued that the situation above is influenced by the economic aspect. All tributes agreed to follow this event not only because of the government's rule, but it is also because of the food and many sources that will be provided by the Capitol to their District if they win.

\section{Power domination in gender, gender, and experience}

The Hunger Games event actually requires one boy and girl to follow this event. no matter they can survive or not, if their names are selected, means they have to follow and face it. People believe that boy and girl have a different rule in life and they both also have different skill in doing something. It can be proved in data 6 "don't be so superior". This utterance occurred when Peeta has a conversation with Katniss. Peeta believes that Katniss does not have enough power and she will not survive in the arena of the Hunger Games. It is because Katniss is a woman and a woman will not have a strong power like a man. The woman is weaker than a man.

Based on Marx in Ismail and Basir about the class struggle, someone who is stronger than the other, that someone will dominate the others. In this case, man is stronger than a woman. This means a woman is under controlled by the men. This idea has a different argument that stated in data 7 "she's survivor, that one", this data is 
stated by Peeta. But it is told by his mother when he wants to leave his District to follow this event. This sentence shows that Katniss is a strong woman. She is even stronger than Peeta. It is because Peeta's mom knows that she always hunts in the forest and she is good in shooting. In other words, as a woman, Peeta's can feel the same thing about what Katniss feels.

\section{Power domination in age}

Age is a thing that influences someone's role in society. When someone is getting older than the other, that someone will have a higher role in a society. It can be from in a small community until a big community. Just an example in a family, the younger brother or sister should obey to the elder brother and sister. This can be proved in this story especially in Katniss' family. In data 8 "Prim, let go, let go". And in data 9 "Then take it. And take care of her". In this situation, order her sister to do something. in data 8 , Katniss orders her sister with a loud command and her sister have to obey it. It is because Prim is her young sister, and as a young sister have to do what the older one says. It also happens to the next data that is data 9. Katniss orders her sister in taking care of their mother before she leaves. Based on Marxist in Gabrenya (2008), this situation is about how Katniss who has the power and uses it. It is proposed the position of the greater power's requirements. It is not only about how Katniss uses that power for the action, competence, expertise but it is considered the behavior which is comfortable and uncomfortable behavior. In data 8, Katniss says "let" means Prim has to do that. Prim has to go by not doing anything. Her sister does not need to say anything instead of against it or even complaints at all.

\section{Power as Capacity}

The underlines are the data which contained power as capacity found in written source The Hunger Games novel. They are as follow:

\section{Power capacity in worrying}

Worrying is a feeling when someone feels unhappy and afraid. If someone is worried about something, then it will make him/her be braver. It can get more motivation to have more power. For example, when someone is worried about the final examination, then she/he will be harder to study. It also can be found in this story, data 1 , I was ill. I could have treated myself if I'd had the medicine I have now. (Chapter 3, p.51). This utterance occurred between Katniss and her mother. Mrs. Everdeen tells her that she does not need to worry about Prim and her mother. Even she is different from the past. At the time, she always gets sick, but she always tries to treat herself. Besides, she could not find any medicines. The sentence above describes that her mother has the power to heal herself alone, it is because of the medicine she had. It can be seen when she says "could". This word indicates her ability in doing something especially to treat herself. Further, based on Lakey (2009), this situation can be categorized as the types of power specified power-from-within. This means when her mom believes herself that she can use the doctor's way in treating an illness. But at the time, it was different. It is because the people' activities are controlled by the Capitol. They are in a hard way when they want to do something.

All the things that Katniss worries about, it could be answered in the Data 2, I'll keep an eye on the little girl. Make sure she's eating. (Chapter 3, p. 54).

This is a way of helping Katniss to make her sure that there will be someone who can give some attention to her mother and sister. He is Gale, her best friend. He and Katniss always hunt some meals in the forest. Katniss always gets some meals by shooting an animal or some, then she takes it home. The two data above indicate the social phenomenon that occurred in Katniss' family. And it may also happen to the other families. This case describes the economical determined power and the social order. This can be investigated by understanding power as the chance of someone or a number of groups to realize their own will to participate or to take in an action. While the economical conditioned indicates that it can be identical to power which is the way of taking the materials. Then, it will happen among the society which is called as the social order. The other data shows in Data 3 The more likable he is, the more deadly he is. (Chapter 5, p. 102). Peeta actually makes Katniss comfortable by holding her hands when they are showing their clothes to all people. But Katniss has a different thought that Peeta will kill her by this way. So, Katniss tries to not close with him at the time. Actually, this event does not only present of having a bad thought among those tributes but also it will show some tricks of the tributes to kill each other. This would be their power of killing someone.

Based on Marxist, the context above indicates that everyone has the motivation to achieve their willingness. Although people may see the position of their power, they have to have the achievement of their power. They want to be saved in their life by balancing their power and the social interaction. By understanding this, it brings our mind the know people's willingness to seek the position of power.

\section{Power capacity in anger}

When someone is getting angry, this means that someone has a strong feeling which makes him/her wants to hurt the other. Similarly, that someone is being unpleasant because of something unfair or hurtful that has happened. This idea shows in this story when the tributes have been angry at the Capitol. It can be proved in Data 4 , I notice a lot of the 
other tributes are shooting us dirty looks, which confirms what I've suspected, we've literally outshone them all. (Chapter 5,p. 101). The performance of the opening of Hunger Games, the Capitol held this ceremony to show all tributes to all Districts that here are the tributes who want to compete for each other. Further, in Data 5, "Oh, no, we're not allowed to eat the crops." (Chapter 15, p. 282). This utterance investigates the conversation between Rue who is from District eleven and Katniss. At the first time, Katniss thought that their District always has more enough food because their District is the only one District that presents more food for the Capitol. She has just realized when Rue tells her that all people who are in their District are not allowed to get those foods. Even they produce them. Additionally, in data 6. They're already taking my future! They can't have the things that mattered to me in the past!" I say. (Chapter 9, p. 167). This is indicated the conversation among Haymitch, Peeta, and Katniss. Haymitch takes the roles of the interviewer. They practice how to interview one another. Because before going to the Cornucopia (which is full of weapons and food), they will have an interview section. This will be held after they show their skill in front of the committee of the Capitol. Moreover, in Data 7, I was shooting and they were ignoring me(Chapter 8, p. 150), this occurs when Katniss is annoyed at the Capitol's committee of the Hunger Games. When the all tributes have to show them their skill, then they will them the score of each tribute. Katniss' turn is already provided. Katniss actually does not want to show them her_secret skill, but because the committee does not look at her when she shoots an object.

\section{Power domination in disappointed}

This situation also occurs in data 8. I've never been a contender in these Games anyway. (Chapter 10, p. 199). On this situation, Peeta actually does not want to follow this Hunger Games event. He feels that he is forced by the Capitol. The Capitol and its committees just choose him without asking first. He just wants to die as himself. This indicates one of the tributes is disappointed at the Capitol because of their way of leading them. The word "contender" means Peeta has to compete to win in this event, but he is actually is not ready yet to face it. Peeta actually had a bad influence on his psychology. Thus, this situation can be categorized into the link of class struggle and the psychology. Gabrenya (2008) emphasizes that the psychology has a relationship with the social class. Peeta tells everything about what he feels like. Additionally, the upper class is the effect of having the lower income of someone's life, Peeta. Peeta is affected by taking his life to obtain his freedom. Similarly, this situation can be categorized in types of power based on Lakey (2009). This is power-over. This means Peeta against to do what the Capitol orders at him.
Additionally, in data 9. "How despicable we must seem to you," he says. (Chapter 5, p. 92). This utterance occurred between Katniss and Cinna. This describes when Katniss thinks that all people who are in the Capitol. She thinks that people are bad at the Capitol even Cinna, her stylist at the first time. Cinna knows what she thinks about, Cinna tells her that she can think like that it is because the Capitol identically bad thing who is always forced their people in doing many things.

Further, in Data 10, It's not really fair to present us as a team and then lock us into the arena to kill each other. (Chapter 5, p. 100). Katniss is the tribute who is from District Twelve feels that the Capitol is not fair when they all are presented as the team but later they will be locked in the arena to kill each other. This occurs when Katniss and her team Peeta and the other tributes present their team to all citizens in the Capitol.

\subsection{Marxism perspective in the concept of power in the Hunger Games}

Actually, the Hunger Games novel consists of two perspectives which are economic background and superstructures. The superstructures can be divided into the political and ideological system. By having all the data findings and their analysis and the discussion, here is represented the Marxism perspective in the concept of power in the Hunger Games. The perspectives are as followed:

- All the things which happened in all twelve Districts (power as capacity), it is caused by the power as domination.

- The power as domination sometimes does not only occur between the upper and lower class but it can also occur between lower and lower class.

To sum up, the Marxism perspective in the concept of power in the Hunger Games are power as capacity is caused by the power as domination, the power as domination does not only occur between upper and lower class but it also happens among the lower class.

\section{CONCLUSION AND SUGGESTION}

\subsection{Conclusion}

Marx's perspective about the two characteristics above that is conducting in The Hunger Games novel, it actually happens between the Capitol as the bourgeois and the people who are in each of twelve Districts as the proletariat. The Capitol has dominated all the Districts, it is because the Capitol has more power to control them. In other words, the Capitol is the higher class than the Districts. By dominating them, so there are many causes arise among them. For example, the Districts try to against the Capitol; the Districts will have not enough diet for their 
life, etc. It indicates the social problem between the upper and lower class. But it actually does not only happen between them, it also happens among the lower classes. Further, the upper class dominates the lower class by forcing them or doing what they do not want to. But, as the result that has analyzed on this research is the upper class sometimes provides a good service for the lower class that has a good power or skill.

Based on the discussion above, the conclusions are followed:

People will dominate the others if they have many experiences, people will dominate the others if they seek the gender both man or woman, people will dominate the others if they seek the gender both man or woman and who do have more experiences, people will dominate the others if they have a higher position than them, and people will dominate the others if they have differentiation ages.

Moreover, people will have more power if they are worried, people will have more power if they are angry, people will have more power if they are disappointed.

\subsection{Suggestion}

Analyzing the concept of power by using Marxist as an approach is a big appreciation and it is not too easy It is because the concept of power which has many essential ideas should be analyzed with Marxist. This research tried to find out the hiding meaning of each example of the concept of power which is helped by Karlberg's and Marx's theory. The Hunger Games novel is one of some novels that can be used for analyzing that concept of power. This novel provides the social class between upper and lower class.

Then, for the next research that wants to conduct the concept of power, it can be analyzed in another literary work like a poem, short story, etc. it is because the concept of power is about human life and the literary works represent the human life. Besides, if the next research that wants to apply Marxist as an approach, the research should be had a deep analysis. It is because of Marxist's perspective about the literary work, it is a product of a specific person or a community and the culture at the exact time. So the reader can get some information clearly and get understanding easily.

\section{REFERENCES}

[1] Afolayan, S. (2011). A Marxist Interpretation of the Dystopian Society in the African. Novel Kemanusiaan

[2] Bertens, H. (2002). Literary Theory the Basic. London and New York: Taylor and Francis e-Library.

[3] Castells, M. (2011). A Network Theory of Power.International Journal of Communication, 5, 773-787.
[4] Cerbaro, R. H. (2011). Competition-trapping the Concept of Power.European Journal of Social Sciences .21(1), 148-153.

[5] Clegg, S.R. \& Haugaard, M (2008). Introduction: Why Power is the Central Concept of the Social Sciences. CLEAG: The SAGE Handbook of Power

[6] Collins, S (2008). The Hunger Gaames. Novelist/Publishing

[7] Dahl, R. A. (2001). The Concept of Power. Behavioral Science .

[8] _ Energy Harvesting from Human Power. (2011). An EPSRC Funded Network.

[9] Eaglaton, Terry. (1976). Marxism and Literary Criticism. Taylor \& e-Library.

[10] Friedkin, N. (1986). A Formal Theory of Social Power. University of California, Ssanta Barbara

[11] Gabrenya, W.K (2003). Culture and Social Class.

[12] Ismail, I., \& Basir, M.(2012), Karl Marx dan Konsep Perjuangan Kelas Sosial. International Journal of Islamic Thought, 1, 27-33

[13] Karlberg, M. (2005). The Power of Discourse and the Discourse of Power: Pursuing Peace through Discourse Intervention. International Journal of Peace Studies, 10(1), 1-23

[14]Lakey, G. (2009). Power Analysis: Types and Sources of Power.Sharing Leadership in Our Organization .

[15]Lewy, S. (2009). Teori tiga. Universitas Indonesia

[16] Lieberman, T. (2013). The Real Hunger Games. The Nation

[17] Manshur, F.M. (2012). Teori Sastra Marxis Dan Aplikasinya Pada Penelitian Karya Sastra Arab Modern. Bahasa dan Seni

[18] Marchsll, T.H. (2009), Citizenship and Social Class. New York

[19] Myers, A. Keller, D. Cook, K. (2014). Bioethics in The Hunger Games (Evaluating the effects of genetic engineering through popular fiction)

[20] Naik, N. (2011). Unlock the Power of Your Alpha Mind and Manifest the Lifestyle of Your Dreams. Alpha Mind System .

[21] Orman, T. (2008). The Hunger Games Student Survival Pack. Scholastic, Incorporated

[22]Plekhanov. G.V. (2007). Masalah-Masalah Dasar Marxisme. Webmaster

[23] Pogreba, M., \& High, H. (n.d.). Literary Criticism: Marxist.

[24] Roback, D. (2012).' Hunger Games' Still Rules in Children's. Publisher Weekly

[25] Robinson, Buccigrossi, and Pfeffer Charles, eds. (2003), Class: Power, Privilege, and Influence in the United State. 
[26] Schoeffel, J. \& Mitchell, P.R. (2001). Understanding Power. New York

[27] Selden, R., Widdowson, P., \& Brooker, P. (2005). A Reader's Guide to Contemporary Literary Theory. Great Britain: Pearson Longman.

[28] Seymour, J. (2001). The Seven Types of Power Problems. Electric Power Research Institute

[29] Steenis, J. V. (2009). The Power of the Autonomous Human.

[30] Sugiyono. (2009). Metode Penelitian Kuantitatif, Kualitatif Dan $R \& D$. Alfabeta Bandung

[31] Swardhani. N. W (2012). Kritik Sastra-Sastra Jepang Review Teori

[32] Wijaya. E. (2008). Pengantar Mengenai Teori Marxis Tentang Hukum. Jurnal Dinamika Hukum, 8(3), 183189

[33] Wohlforth, C. W. (2007). Testing Balance-of-Power Theory in World History. European Journal of International Relation, 13(2), 155-185

[34] Windridge, K, Ockleford, E \& Hancock, B (2009). An Introduction to Qualitative Research. National Institute for Health Research

[35]Zulfebriges. (2003). Teori Media-Marxist: Sebuah Pengantar.Mediator 